\title{
Transcriptome comparison of winter and spring wheat responding to low temperature
}

\author{
Patrick J. Gulick, Simon Drouin, Zhihua Yu, Jean Danyluk, Guylaine Poisson, \\ Antonio F. Monroy, and Fathey Sarhan
}

\begin{abstract}
Freezing tolerance in plants is a complex trait that occurs in many plant species during growth at low, nonfreezing temperatures, a process known as cold acclimation. This process is regulated by a multigenic system expressing broad variation in the degree of freezing tolerance among wheat cultivars. Microarray analysis is a powerful and rapid approach to gene discovery. In species such as wheat, for which large scale mutant screening and transgenic studies are not currently practical, genotype comparison by this methodology represents an essential approach to identifying key genes in the acquisition of freezing tolerance. A microarray was constructed with PCR amplified cDNA inserts from 1184 wheat expressed sequence tags (ESTs) that represent 947 genes. Gene expression during cold acclimation was compared in 2 cultivars with marked differences in freezing tolerance. Transcript levels of more than 300 genes were altered by cold. Among these, 65 genes were regulated differently between the 2 cultivars for at least 1 time point. These include genes that encode potential regulatory proteins and proteins that act in plant metabolism, including protein kinases, putative transcription factors, $\mathrm{Ca}^{2+}$ binding proteins, a Golgi localized protein, an inorganic pyrophosphatase, a cell wall associated hydrolase, and proteins involved in photosynthesis.
\end{abstract}

Key words: wheat microarray, expression profile, plant transcription, cold-regulated genes, freezing tolerance, cold acclimation, winter hardiness, stress genes, gene regulation, wheat transcriptome.

Résumé : La tolérance au gel chez les plantes est un caractère complexe qu'on rencontre chez plusieurs plantes au cours de la croissance à de faibles températures (au-dessus du point de congélation), un phénomène appelé acclimatation au froid. Ce processus est régulé par un système multigénique qui produit une grande variation quant au degré de tolérance au gel parmi différents cultivars du blé. Les puces à ADN constituent une approche puissante et rapide en vue de l'identification de gènes. Chez des espèces telles que le blé, pour lesquelles le criblage à grande échelle de mutants ou la transgenèse ne sont pas présentement pratiques, la comparaison de différents génotypes constitue une approche essentielle pour l'identification de gènes clés dans l'acquisition de la tolérance au gel. Une puce à ADN a été constituée avec des inserts de clones ADNc amplifiés par PCR, ces clones provenant de 1184 EST (étiquettes de gènes exprimés) et représentant 947 gènes. L'expression génique au cours de l'acclimatation a été comparée chez 2 cultivars présentant une tolérance au gel très contrastée. L'abondance de plus de 300 gènes était modifiée par le froid. Parmi ceux-ci, 65 gènes présentaient une régulation différente chez les 2 cultivars pour au moins 1 des temps d'échantillonnage. On y retrouve des gènes qui codent pour de possibles protéines régulatrices et des protéines impliquées dans le métabolisme dont des protéines kinases, des facteurs de transcription putatifs, des protéines liant le $\mathrm{Ca}^{2+}$, une protéine localisée dans le Golgi, une pyrophosphatase inorganique, une hydrolase associée à la paroi cellulaire, ainsi que des protéines impliquées dans la photosynthèse.

Mots clés : puce à $\mathrm{ADN}$ pour le blé, profil d'expression, transcription chez les plantes, gènes régulés par le froid, tolérance au gel, acclimatation au froid, résistance au froid, gènes de stress, régulation génique, transcriptome du blé.

[Traduit par la Rédaction]

Received 14 December 2004. Accepted 20 April 2005. Published on the NRC Research Press Web site at http://genome.nrc.ca on 21 October 2005.

Corresponding Editor: F. Belzile.

P.J. Gulick, ${ }^{1}$ S. Drouin, ${ }^{2}$ Z. Yu, and A.F. Monroy. Department of Biology and Centre for Structural and Functional Genomics, Concordia University, 7141 Sherbrooke West, Montréal, QC H4B 1R9, Canada.

J. Danyluk, and F. Sarhan. Département des sciences biologiques, Université du Québec à Montréal, Case postale 8888, Succursale Centre-ville, Montréal, QC H3C 3P8, Canada.

G. Poisson. ${ }^{3}$ Laboratoire de combinatoire et d'informatique mathématique, Université du Québec à Montréal, Case postale 8888, Succursale Centre-ville, Montréal, QC H3C 3P8, Canada.

${ }^{1}$ Corresponding author (e-mail: pgulick@alcor.concordia.ca).

${ }^{2}$ Present address: Institut de Recherches Cliniques de Montréal, 110 avenue des Pins Ouest, Montréal, QC H2W 1R7, Canada. ${ }^{3}$ Present address: Department of Information and Computer Science, University of Hawaii at Manoa, 1680 East-West Road, Honolulu, HI 96822-2233 USA. 


\section{Introduction}

Low temperature (LT) is a major cause of crop damage, and the ability of plants to develop freezing tolerance (FT) during cold acclimation is a determining factor in their survival. Exposure of plants to LT produces morphological, biochemical, and physiological changes that are often highly correlated with plant FT and winter survival. There is a great deal of genetic variation both between and within species for the process of cold acclimation and in the ultimate degree of FT that can be achieved. Molecular and genetic analyses have demonstrated differential gene expression and the increased accumulation of several proteins during cold acclimation in several species. The complexity of the LT response creates a challenge to differentiate the genes responsible for LT acclimation and cold hardiness from those associated with metabolic adjustment to LT. Identifying the genes contributing to FT and understanding how they are regulated is important in establishing the appropriate strategy for the improvement of FT in crop species. To achieve this goal, global approaches to identifying the genetic components involved in this mulitgenic trait are essential. Microarray analysis to characterize gene expression profiles for large numbers of transcripts has been used to describe the response to environmental stresses in several species including Arabidopsis for cold, drought, and salt (Seki et al. 2001; Fowler and Thomashow 2002; Kreps et al. 2002), recovery from dehydration (Oono et al. 2003) and oxidative stress (Desikan et al. 2001); rice for response to salt stress (Kawasaki et al. 2001); and in maize for response to UV radiation (Casati and Walbot 2003). The large number of stress-regulated genes that were detected by these studies indicates that transcript profiling could readily be applied to comparative studies of cold hardy genetic stocks.

Wheat cultivars have a remarkable range of FT and thus are an excellent model to study this trait. Several LT responsive genes have been identified in wheat using differential screening (Houde et al. 1992; Chauvin et al. 1993; Danyluk et al. 1994; Danyluk et al. 1996; Danyluk 1997; N'Dong et al. 2002; Breton et al. 2003). However, these methods are limited and time consuming; moreover, they do not describe the global view of coordinated expression and the interactions among the expressed genes. To accelerate the pace of discovery, 1200 expressed sequence tags (ESTs) were generated from clones from a cDNA library of cold-acclimated winter wheat and used to construct a cDNA amplicon microarray. The LT-regulated gene expression profile of winter wheat 'Norstar', which has a lethal temperature for $50 \%$ of the seedlings $\left(\mathrm{LT}_{50}\right)$ of $-19^{\circ} \mathrm{C}$, was compared with that of spring wheat 'Glenlea', which has an $\mathrm{LT}_{50}$ of $-8{ }^{\circ} \mathrm{C}$. The objective of this comparison was to differentiate genes associated with the development of FT from those associated with LT stress. We report changes in the expression pattern of a significant portion of the genes probed by the microarray over the course of 36 days of cold acclimation. More importantly, we identified a subset of genes with significant differences in regulation between the 2 cultivars. This subset includes genes with regulatory functions that may prove to play an important role in the acquisition of FT.

\section{Materials and methods}

\section{Plant material and growth conditions}

The spring wheat Triticum aestivum L. 'Glenlea', $\mathrm{LT}_{50}$ $-8{ }^{\circ} \mathrm{C}$, and the winter wheat Triticum aestivum L. 'Norstar', $\mathrm{LT}_{50}-19^{\circ} \mathrm{C}$, were used in the microarray analysis. Further characterization of the expression of selected genes was done using Triticum aestivum L. 'Clair', $\mathrm{LT}_{50}-17{ }^{\circ} \mathrm{C}$, a derivative of 'Norstar'. Seeds were germinated in moist sterilized vermiculite for 5 days in the dark and 2 days under artificial light. Cool-white fluorescent and incandescent lighting was combined to provide an irradiance of $250 \mu \mathrm{mol} \cdot \mathrm{m}^{-2} \cdot \mathrm{s}^{-1}$. The temperature was maintained at $25 \pm 1{ }^{\circ} \mathrm{C}(15-\mathrm{h}$ photoperiod) during the day and $20 \pm 1{ }^{\circ} \mathrm{C}$ during the night. The relative humidity was $70 \% \pm 5 \%$. Seedlings were watered daily with a nutrient solution $(0.5 \mathrm{~g} / \mathrm{L}$ of $\mathrm{N}: \mathrm{P}: \mathrm{K}$ at a ratio of $20: 20: 20)$. At the end of this period, control plants were maintained under the same conditions of light and temperature for an additional 1 and 6 days. Cold acclimation was performed by subjecting germinated seedlings to a temperature of $6 \pm 1{ }^{\circ} \mathrm{C}$ during the day $\left(10-\mathrm{h}\right.$ photoperiod and $\left.175 \mu \mathrm{mol} \cdot \mathrm{m}^{-2 \cdot} \mathrm{s}^{-1}\right)$ and $2 \pm 1{ }^{\circ} \mathrm{C}$ during the night for 1,6 , and 36 days. Control seedlings grown 1 and 6 days beyond the 7 days of germination at $25{ }^{\circ} \mathrm{C}-22{ }^{\circ} \mathrm{C}$ (day-night) are referred to as Control1-day plants and Control-6-days plants, respectively. Based on seedling dry mass, Control-1-day plants and Control-6days plants have the same phenological phase as seedlings that were cold acclimated for 6 and 36 days, respectively. Gene induction in plants that were cold acclimated for 1 and 6 days was measured by comparison with Control-1-day plants. Plants cold treated for 36 days were compared with Control-6-days plants. Plants were harvested $3 \mathrm{~h}$ before the end of the day cycle. The aerial part of 40-80 cold-treated seedlings, including the meristematic crown and leaves $(10 \mathrm{~g})$, was used for the extraction of total RNA according to a method described previously (Danyluk and Sarhan 1990).

\section{cDNA library construction and EST sequencing}

Ribonucleic acid from meristematic crown and leaves of 'Norstar' seedlings cold treated for 1 day was used for construction of a cDNA library in Lambda ZAP $^{\circledR}$ II vector (Stratagene, La Jolla, California, USA) in random orientation and rescued as pBluescript $\mathrm{SK}^{-}$plasmid by in vivo excision. Details of cDNA library construction are provided in the supplementary materials and methods.

Virtual subtraction was carried out to enrich cDNAs from low abundance mRNAs. Colonies were transferred into 96-well plates containing Luria-Bertani (LB) with $100 \mathrm{mg} / \mathrm{L}$ ampicillin and grown overnight at room temperature. Plates were replicated onto nylon membranes (Hybond-N., Amersham Pharmacia Biotech Inc., Piscataway, New Jersey, USA) and grown on LB agar with $100 \mathrm{mg}$ ampicillin/L overnight at $37^{\circ} \mathrm{C}$. Colonies were lysed, denatured, and neutralized according to standard methodology (Sambrook et al. 1989). First strand cDNA from 1 day cold-acclimated 'Norstar' was labeled with digoxigenin, and hybridization and detection were done according to the DIG High Prime DNA Labeling and Detection Starter Kit II instructions (Roche Molecular Bio- 
chemicals, Mannheim, Germany). Approximately 30\% of colonies showing the lowest hybridization signal were chosen for sequencing.

Plasmids were prepared with the QIAprep Miniprep Kit (QIAGEN, Mississauga, Ontario). Expressed sequence tags were generated by single-pass sequencing of cDNA inserts using either the dideoxynucleotide chain termination method (T7 sequencing kit, Amersham Pharmacia, Uppsala, Sweden) and gel electrophoresis, or the dye terminator sequencing kit (Beckman Coulter Inc. Fulerton, Calif.) and the Beckman CEQ2000 automated sequencer (Center for Structural and Functional Genomics, Concordia University, Montréal, Quebec). The quality of ESTs was assessed using phred/phrap software (Ewing and Green 1998; Ewing et al. 1998; www.phrap.org), and vector and low quality regions were trimmed using LUCY (The Institute for Genomic Research (TIGR), Rockville, Maryland, USA). The ESTs were queried against the TIGR gene indices using Wheat Version 6.0, Barley Version 6.0, Rice Version 12.0, and Arabidopsis Version 10.0 indices and annotated using the TIGR descriptions. Some additional annotation of differentially expressed genes was taken from GenBank nr data set. Independent members of gene families were scored as individual genes. Thus, some independent clones on the microarray may have similar annotations.

\section{cDNA microarray}

The cDNA inserts for each EST were amplified from the plasmids using a protocol from Hegde et al. (2000) with some modifications (details of the microarray construction are provided in the supplementary materials). ${ }^{3}$ Clones were not rearranged from the original 96-well plates used for EST sequencing to avoid picking and tracking errors. After expression analysis, approximately 190 clones that showed changed expression during cold acclimation were chosen for verification by resequencing. Microarrays were spotted on Corning $^{\circledR}$ CMT-GAPS 2 or UltraGAPS ${ }^{\mathrm{TM}}$ (Corning Life Sciences, Corning, N.Y.) glass slides using a Virtek arrayer robot (Virtek, Waterloo, Ontario) equipped with Telechem Stealth II quill pins (TeleChem International, Sunnyvale, Calif.) in a 24-pin configuration. The spots were spaced on a 0.3 -mm grid. Each product was spotted 4 times, 2 spots side by side, in 2 locations. The target cDNA was generated by indirect labeling with the initial incorporation of aminoallyldUTP (Sigma, Oakville, Ontario) during reverse transcription and subsequent reaction with $\mathrm{Cy}-3^{\mathrm{TM}}$ or $\mathrm{Cy}-5^{\mathrm{TM}}$ monoreactive ester dyes (Amersham Pharmacia, Uppsala, Sweden). For each pair of comparisons, 3 to 6 replicate hybridizations were carried out. For each experiment, at least 1 dye-swap slide was done in which the labeling of control and treatment target cDNA with $\mathrm{Cy}-3$ and $\mathrm{Cy}-5$ were reversed. (The details of the labeling protocols and hybridization protocols are provided in the supplementary materials. ${ }^{3}$ )

\section{Microarray scanning and data analysis}

The slides were scanned on an Axon 4000b scanner (Molecular Devices, Sunnyvale, Calif.). The images were saved as multichannel TIFF files and the images were analyzed using the GenePix 3.0 software (Molecular Devices). Low quality spots including misshapen spots and those obscured by dust motes, scratches, or buffer spots were flagged and subsequently disregarded in the analysis. The statistical analysis was done using the GeneSpring software package version 5.0.3 (Silicon Genetics, Redwood City, California, USA). The 4 replicate spots on each slide were averaged. The dye-swap normalization method, on a per spot basis, was first used in applicable experiments. Furthermore, all slides were normalized, on a per chip basis, using the Lowess regression method. Variances were calculated using cross-gene error model and on-chip replicates. Changes of transcript levels during cold acclimation were determined by comparing the treatment to control plants for each genotype. This comparison used the multiple testing correction of the Benjamini-Hochberg false discovery rate procedure with a cutoff of 0.05 (Benjamini and Hochberg 1995). Then the transcript levels in the 2 cultivars were compared directly by comparison of target cDNAs tested with the hypothesis that there were no differences in expression in the 2 cultivars (WT/ST $=1)$. Gene expression in control plants was not measured directly. (The arithmetic calculation of those values based on other comparisons is presented in the supplementary materials.) ${ }^{3}$

Clustering analysis was performed using the Genesis software (Sturn et al. 2002). The analysis included genes that had altered expression during at least 1 time point and those genes that had valid data for all time points in at least 1 cultivar. Genes with the same functional annotation that were not members of the same contig were kept as independent sets of values. The analysis included 215 and 136 genes from the winter and spring data sets, respectively; 125 of the genes were common to both data sets. Data were averaged for the replicates for each feature of each genotype at each time point, and clustering was based on the 3 expression ratio values at the 3 time points of 1, 6, and 36 days. Expression values for the same gene measured in each of the 2 cultivars were entered into the analysis as independent sets of values in a single clustering analysis to detect pattern similarity and differences between the 2 cultivars. An averagelinkage hierarchical clustering method that uses Euclidian distances was employed.

\section{RT-PCR measurement of transcript level of selected genes}

Total RNA samples were treated with DNAse I (Ambion Inc., Austin, Texas, USA). RNA samples were quantified by spectrometer, and $5 \mu \mathrm{g}$ of RNA was used for reverse transcription using Invitrogen Superscript II and oligo-dT primer (Invitrogen Canada, Burlington, Ontario) according to the manufacturer's recommendation. One-fiftieth volume of each cDNA was used for PCR amplification by Taq DNA Polymerase (MBI Fermentas, Burlington, Ontario) under the following conditions: $94{ }^{\circ} \mathrm{C}$ for 2 min; followed by 35 cycles at $94{ }^{\circ} \mathrm{C}$ for $30 \mathrm{~s}, 57{ }^{\circ} \mathrm{C}$ for $30 \mathrm{~s}$, and $72{ }^{\circ} \mathrm{C}$ for $45 \mathrm{~s}$. The primers for each gene are listed in supplementary Table S3. ${ }^{3}$ To

\footnotetext{
${ }^{3}$ Supplementary data for this article are available on the Web site or may be purchased from the Depository of Unpublished Data, Document Delivery, CISTI, National Research Council Canada, Ottawa, ON K1A 0S2, Canada. DUD 4007. For more information on obtaining material refer to http://cisti-icist.nrc-cnrc.gc.ca/irm/unpub_e.shtml.
} 
rule out gDNA contamination, PCRs were run with untranscribed RNA samples as template. The ubiquitin cDNA was amplified as an internal control (Yan et al. 2003).

\section{Results and discussion}

\section{EST annotation and microarray design}

High quality EST sequences were generated by singlepass sequencing of $1187 \mathrm{cDNA}$ clones from a cDNA library made from crown and shoots of LT-treated wheat seedlings. Annotation for the wheat ESTs derived from BLAST queries against the TIGR gene indices or the GenBank nr database assigned a functional description to 783 ESTs. Of these, 386 ESTs were classified either as without functional descriptions or as unknown, hypothetical, putative, ESTs or open reading frames. Contig assembly within our EST set and clustering with wheat tentative contigs (TCs) in the TIGR database indicated the EST collection contained 801 singletons and 147 contigs that in total provided a unigene set of 948 genes. We constructed a wheat microarray with PCR amplified inserts from 1187 ESTs without rearrangement of the clones from the original sequencing master plates; this was done to avoid tracking errors. DNA sequences for ESTs used in these studies are presented in supplementary Table S1. ${ }^{3}$ Approximately $50 \%$ of spots were detected with significant signals above background. Resequencing of approximately 190 selected clones of cold-regulated genes indicated accurate clone identification and tracking.

\section{Gene regulation during cold acclimation}

Both highly cold-tolerant and less tolerant cultivars increase cold tolerance during cold acclimation. In a effort to detect genes that may play important roles in cold acclimation and increased freezing tolerance, we have directed our analysis to the detection of genes that are differently regulated in the 2 cultivars. Gene expression was measured in cultivars 'Norstar' $\left(\mathrm{LT}_{50}-19{ }^{\circ} \mathrm{C}\right)$ and 'Glenlea' $\left(\mathrm{LT}_{50}-8{ }^{\circ} \mathrm{C}\right)$ after 1, 6, and 36 days of cold acclimation. Microarray hybridizations were analyzed with 2 approaches: $(i)$ measurement of gene induction and repression by comparison of target cDNAs from cold-acclimated and nonacclimated control plants, and (ii) direct comparison of pairs of target cDNAs derived from 'Norstar' and 'Glenlea' that had been cold acclimated for 6 or 36 days. The experimental design, shown in Fig. 1, allowed a thorough comparison of the gene expression profiles of the 2 cultivars. Direct comparison of mRNA populations from 1 cultivar taken at 2 time points or comparison of the 2 cultivars with samples taken from identical treatments were used to derive most of the expression data, but the design allowed additional data to be deduced by calculation. For example, ratio of expression levels in control plants of the 2 cultivars was calculated from ratio of gene induction between 1 and 6 days in the 2 cultivars divided by the ratio of expression between the 2 cultivars measured at 6 days of cold acclimation.

There were 337 genes with altered levels of expression that were statistically significant with $P<0.05$ and that had changes in expression greater than a threshold of 1.5 or less than 0.66 for at least 1 time period. Genes meeting these criteria are the basis of subsequent analysis; detailed data for these genes are listed in supplementary Table $\mathrm{S}^{3}$ and sum-
Fig. 1. The experimental design is based on the series of pairwise comparisons. Numbers indicate the number of days plants were grown at the indicated experimental temperatures. Before day 1 of the experiment, all plants had been germinated and grown for 7 days at $24{ }^{\circ} \mathrm{C}$. $\mathrm{N}$, winter wheat 'Norstar'; G, spring wheat 'Glenlea'.

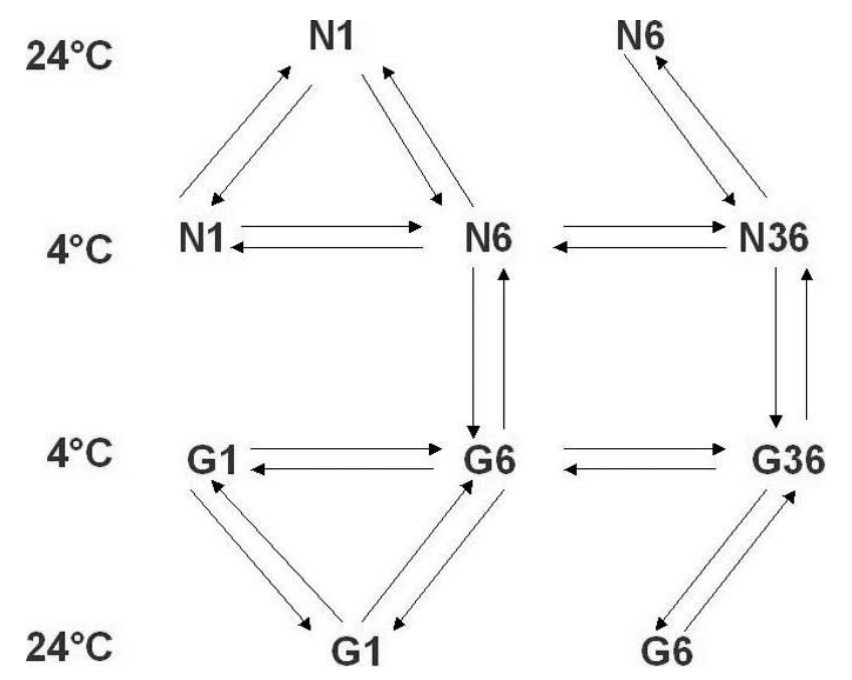

Table 1. Genes with changes in expression 1.5-fold or more and $P$-value $<0.05$ in the winter wheat 'Norstar' and the spring wheat 'Glenlea' after 1, 6, and 36 days of cold acclimation at $4{ }^{\circ} \mathrm{C}$.

\begin{tabular}{llllll}
\hline & \multicolumn{2}{l}{ Upregulated genes } & & \multicolumn{2}{l}{ Downregulated genes } \\
\cline { 2 - 3 } $\begin{array}{lllll}\text { Days of } \\
\text { treatment }\end{array}$ & 'Norstar' & 'Glenlea' & & 'Norstar' & 'Glenlea' \\
\hline 1 & 74 & 44 & 78 & 32 \\
6 & 90 & 66 & 115 & 60 \\
36 & 57 & 45 & 77 & 27 \\
\hline
\end{tabular}

marized in Table 1. The use or choice of threshold values is somewhat debatable since even small changes in gene expression may be biologically important, especially for regulatory genes. The choice of higher thresholds used elsewhere is influenced by higher levels of statistical confidence associated with larger changes in RNA signals; however, there are exceptions to the trend to have lower $P$-values associated with larger changes in gene expression. The 1.5 and 0.66 threshold values for data presented in supplementary Table $\mathrm{S}^{3}$ were chosen to give an ample presentation of the data; $P$-values for each expression ratio are also given in the table.

In the winter wheat cultivar 'Norstar', levels of the transcripts of 309 genes were altered during the cold acclimation. Among these genes, 170 were significantly changed at a single time point, 96 were changed at 2 time points, and 43 had altered expression at all 3 time points. In the spring wheat cultivar 'Glenlea' levels of 166 gene transcripts were altered during cold acclimation. Among these genes, 88 were significantly changed at a single time point, 48 were changed at 2 time points, and 30 had altered expression at all 3 time points. The higher number of genes with altered expression that were detected in winter wheat is partially due to the greater degree of experimental replication carried out with 'Norstar'. Thus, more genes with relatively small 
Table 2. Genes with different induction in winter and spring wheat at 1 day of cold acclimation. W/S, winter/spring; LT, low temperature.

\begin{tabular}{|c|c|c|c|c|c|c|}
\hline Clone & $\begin{array}{l}\text { TIGR } \\
\text { accession No. }\end{array}$ & Annotation & $\begin{array}{l}\text { Control } \\
\text { W/S }\end{array}$ & $\begin{array}{l}\text { Spring } \\
\text { induction }\end{array}$ & $\begin{array}{l}\text { Winter } \\
\text { induction }\end{array}$ & $\begin{array}{l}\text { Induction } \\
\mathrm{W} / \mathrm{S}\end{array}$ \\
\hline $\mathrm{J} 470$ & TC85079 & LEA14-A & 5.69 & $4.56^{*}$ & $11.55^{*}$ & $2.53 *$ \\
\hline J517 & TC91471 & LT 101 putative membrane protein & 4.90 & $7.72 *$ & $4.50 *$ & $0.58 *$ \\
\hline $\mathrm{J} 275$ & TC87867 & ESI3/LT $101 \mathrm{LT}$ and salt induced & 4.92 & $9.93 *$ & $5.08 *$ & $0.51 *$ \\
\hline $\mathrm{J} 330$ & TC87536 & LEA/RAB/COR cold-responsive protein & 2.60 & $14.59 *$ & $6.85^{*}$ & $0.47 *$ \\
\hline J666 & TC69676 & WCOR14a - cold-regulated protein & 2.60 & $14.44 *$ & $5.55^{*}$ & $0.38 *$ \\
\hline
\end{tabular}

Note: TIGR accessions are the most similar sequence in the TIGR Wheat Gene Index, V6. Control W/S is the relative level of mRNA in control winter wheat plants compared with control spring wheat plants. It is calculated indirectly by dividing the relative level of mRNA in the 2 cultivars by the relative rate of induction at 6 days of accumulation.

* Statistical significance criteria is $P$-value $\leq 0.05$.

changes in expression could be classified as having statistically significant changes. The large proportion of genes that were seen to be regulated by cold treatment is somewhat higher than the approximately $25 \%$ of the genes of Arabidopsis that were seen to have changes in mRNA levels of 2 -fold or more when the plants are treated with LT alone (Kreps et al. 2002). This is not surprising since the cDNA library that was the source of clones for this array was derived from cold-treated plants and is expected to be enriched for cold-induced genes. In addition, the high proportion of genes whose altered expression was detected at only 1 of 3 time points indicates that the number of genes classified as regulated by cold is highly dependent on the number of times plants are sampled during the course of cold acclimation.

\section{Differences in gene regulation in spring and winter wheat}

To compare gene expression between the winter and spring cultivars, first gene expression was evaluated by comparing up- and down-regulation at 1, 6, and 36 days acclimation. Here, cDNA from cold-treated plants was compared with cDNA from appropriate controls from each cultivar. Then, direct comparisons were made by hybridizing cDNA from 'Norstar' with cDNA from 'Glenlea' plants acclimated to cold for the same period. The first approach can detect genes that have different levels of induction or repression in the 2 cultivars that are not necessarily classified as induced or repressed in the individual cultivar analysis. For example, genes that are slightly downregulated in 1 cultivar and slightly upregulated in the other cultivar may not be scored as significantly altered in individual comparisons but may be significantly different in a comparison of the 2 cultivars. A total of 87 genes were differentially regulated in the 2 genotypes for at least 1 time point. Data from these comparisons are shown in Tables 2, 3, and 4 .

At 1 day of cold acclimation, 5 genes had significant differences in upregulation in the 2 cultivars; 1 was more strongly induced in winter wheat and 4 were more strongly induced in spring wheat (Table 2). After 6 days of cold acclimation, 57 genes had significant differences in expression between the 2 cultivars (Table 3). Among these, 37 genes were more strongly induced or had higher steady-state levels of mRNAs in winter wheat than in spring wheat. After 36 days of cold acclimation, 41 genes had different levels of expression or changes of expression in the 2 cultivars (Table 4). Among these, 14 were more strongly induced or expressed in winter wheat, than in spring wheat. Twenty- four genes had a winter induction / spring induction value less than 0.66; the trend of this group of genes is that they were strongly upregulated or near control levels in spring wheat and at control levels or downregulated in the winter cultivar.

The majority of genes that were differentially regulated between the cultivars were different at only 1 time period. Only 15 genes had different expression in the 2 cultivars at 2 time periods, and 1 gene (J275) was differentially expressed at all 3 time periods. This suggests that a more thorough sampling during the time course of cold acclimation would likely detect additional differences. The majority of the genes that had significant differences in expression in the 2 cultivars had somewhat parallel patterns of expression, in that they were up- or down-regulated in both cultivars, but had greater changes in 1 of the cultivars.

Direct comparison of target cDNA from the 2 cultivars after 6 and 36 days of cold acclimation detected differences in expression that are not detected by comparison of gene induction and repression in the 2 cultivars as measured by comparison of control and cold-acclimated plants. This may be the case if the levels of expression are not the same in control plants for the 2 cultivars and because of reduced experimental variance since the comparison is based on 2 sample sets rather than the 4 sets that are required to compare gene induction between the 2 cultivars. Though many of the same genes were detected by the 2 methods of comparison, the direct comparison of the 2 cultivars allowed the detection of an additional 14 differentially expressed genes in the 2 cultivars at 6 days, 8 of these were more strongly expressed in 'Norstar' than in 'Glenlea' (Tables 3 and 4). Four additional genes that were differentially expressed in the 2 cultivars were detected at 36 days of cold treatment. All of the 4 genes were more strongly expressed in 'Glenlea' than in 'Norstar'.

The majority of transcripts that were seen to be more strongly induced in 1 cultivar also had higher levels of mRNA levels in that cultivar, though this was not universally the case. For example, several genes including J302, J517, $\mathrm{J} 275$, J666, and J854 have higher levels of induction in spring wheat than in winter wheat after 6 days of acclimation but have higher expression in winter wheat than in spring wheat, presumably because they had higher basal levels of expression in the nonacclimated controls on day 1. This indicates that the relative level of expression in nonacclimated controls in the 2 cultivars is also different. The relative level of gene expression of the control plants of the 
Table 3. Genes with different induction or expression in winter and spring wheat at 6 days of cold acclimation. W/S, winter/spring; LT, low temperature.

\begin{tabular}{|c|c|c|c|c|c|c|c|}
\hline Clone & $\begin{array}{l}\text { TIGR } \\
\text { accession No. }\end{array}$ & Annotation & $\begin{array}{l}\text { Control } \\
\text { W/S }\end{array}$ & $\begin{array}{l}\text { Spring } \\
\text { induction }\end{array}$ & $\begin{array}{l}\text { Winter } \\
\text { induction }\end{array}$ & $\begin{array}{l}\text { Induction } \\
\mathrm{W} / \mathrm{S}\end{array}$ & $\begin{array}{l}\text { Expression } \\
\text { W/S }\end{array}$ \\
\hline $\mathrm{C} 95$ & TC87317 & Actin depolymerization factor & 1.05 & $3.76^{*}$ & $12.14 *$ & $3.23 *$ & $3.40 *$ \\
\hline E31_F & ТC92493 & COR39 protein & 1.19 & $6.52 *$ & $20.50 *$ & $3.14 *$ & $3.75^{*}$ \\
\hline J619 & TC87319 & WCOR719 cold & 0.83 & $2.91 *$ & $7.49 *$ & $2.57 *$ & $2.14 *$ \\
\hline J806 & TC68452 & Lipid transfer protein & 0.75 & $5.99 *$ & $14.40 *$ & $2.41 *$ & $1.79 *$ \\
\hline J642 & TC79747 & Unknown protein & ND & ND & $6.85^{*}$ & ND & $2.87 *$ \\
\hline J822 & ТC89914 & Guanine regulatory protein & ND & ND & $7.02 *$ & ND & $2.49 *$ \\
\hline J657 & TC65078 & Gamma-thionin precursor & ND & ND & $2.86^{*}$ & ND & $2.35 *$ \\
\hline $\mathrm{J} 733$ & TC94499 & Golgi-localized protein & ND & ND & ND & ND & $2.04 *$ \\
\hline J459 & TC85842 & Probable acclimation protein & 1.24 & $7.49 *$ & $14.65^{*}$ & 1.96 & $2.43 *$ \\
\hline $\mathrm{C} 272$ & TC65072 & Gamma-thionin precursor & 0.71 & 1.03 & $1.98 *$ & $1.93 *$ & 1.37 \\
\hline $\mathrm{J} 765$ & TC69449 & Chitinase 2 & 1.47 & $3.74 *$ & $6.88 *$ & $1.84^{*}$ & $2.70 *$ \\
\hline B60_F & TC67796 & WCOR825 cold-acclimation protein & 0.73 & 1.16 & $2.09 *$ & $1.81^{*}$ & 1.32 \\
\hline C197 & TC87822 & Unknown protein & 0.89 & 1.05 & $1.82 *$ & 1.74 & $1.55^{*}$ \\
\hline C55 & TC67115 & Cold-acclimation protein & 1.33 & 1.55 & $2.65 *$ & 1.70 & $2.26 *$ \\
\hline E25_F & TC83987 & Unknown protein & ND & 0.91 & $1.55^{*}$ & $1.70 *$ & ND \\
\hline J862 & TC88307 & LT-induced lipocalin & 0.69 & $1.38^{*}$ & $2.34 *$ & $1.69 *$ & 1.18 \\
\hline C161 & TC96342 & LT-induced protein & 1.27 & $11.75^{*}$ & $19.92 *$ & 1.69 & $2.15^{*}$ \\
\hline J882 & TC63551 & Inorganic pyrophosphatase & 0.68 & $1.57 *$ & $2.63 *$ & $1.68 *$ & 1.15 \\
\hline C290 & TC92066 & Ice-recrystallization inhibition protein & 0.93 & $1.50 *$ & $2.42 *$ & $1.61 *$ & 1.51 \\
\hline J680 & TC79239 & Ice-recrystallization inhibition protein & 1.33 & $5.19 *$ & $8.17 *$ & $1.57 *$ & $2.10 *$ \\
\hline $\mathrm{C} 108$ & TC93229 & Unknown protein F15K9.6 & 1.16 & $2.12 *$ & $3.29 *$ & $1.55^{*}$ & $1.81 *$ \\
\hline C205 & TC64307 & Ubiquitin & 0.74 & 1.09 & $1.67 *$ & $1.52 *$ & 1.12 \\
\hline C653 & TC63643 & Carbonic anhydrase & 0.75 & $0.37 *$ & $0.32 *$ & 0.85 & $0.64 *$ \\
\hline J517 & TC91471 & Blt101.2. LT-induced protein & 2.43 & $4.81 *$ & $3.87 *$ & $0.81 *$ & $1.96^{*}$ \\
\hline $\mathrm{J} 275$ & TC87867 & ESI3 LT, NaCl-induced protein & 2.33 & $4.99 *$ & $4.02 *$ & $0.80 *$ & $1.87 *$ \\
\hline JB018 & TC65343 & Ribulose-1,5-bisphosphate carboxylase & 0.77 & $0.44 *$ & $0.33^{*}$ & 0.76 & $0.59 *$ \\
\hline $\mathrm{J} 302$ & TC87869 & ESI3 LT, NaCl-induced protein & 2.84 & $5.87 *$ & $4.42 *$ & $0.75^{*}$ & $2.14 *$ \\
\hline C302 & CA630452 & Hypothetical protein & 2.13 & $5.87 *$ & $4.42 *$ & 0.75 & $1.60 *$ \\
\hline J883 & TC64211 & Carbonic anhydrase & 0.96 & $0.58 *$ & $0.39 *$ & 0.68 & $0.66^{*}$ \\
\hline E32_F & TC65820 & Nonspecific lipid-transfer protein & 1.14 & $3.33 *$ & $2.21 *$ & $0.66^{*}$ & 0.76 \\
\hline $\mathrm{C} 86$ & TC84168 & Glycine rich protein & 1.92 & $12.79 *$ & $8.27 *$ & $0.65^{*}$ & 1.24 \\
\hline $\mathrm{C} 170$ & TC63101 & Hypothetical protein & 1.40 & $1.57 *$ & $0.81 *$ & $0.52 *$ & 0.72 \\
\hline F29_R & TC93925 & LRK19 receptor-like kinase & 1.28 & $2.17 *$ & 1.12 & $0.52 *$ & 0.66 \\
\hline S15_F & CA698312 & Putative aspartate-tRNA ligase & ND & 1.26 & $0.65 *$ & $0.51 *$ & ND \\
\hline J893 & CA621935 & Alpha-soluble NSF attachment protein & ND & 1.28 & $0.63 *$ & $0.50 *$ & ND \\
\hline J851 & TC64697 & C13 endopeptidase NP1 precursor & ND & 1.30 & $0.63 *$ & $0.49 *$ & ND \\
\hline $\mathrm{C} 75$ & BQ170273 & Peptidase-like protein & 1.40 & $2.03 *$ & 0.98 & $0.48 *$ & 0.68 \\
\hline $\mathrm{J} 279$ & TC72165 & Unknown Triticae protein & 1.51 & $1.98 *$ & 0.90 & $0.46^{*}$ & $0.69 *$ \\
\hline J666 & TC69676 & WCOR14a, cold-responsive protein & 3.67 & $18.85^{*}$ & $8.41 *$ & $0.45^{*}$ & $1.64 *$ \\
\hline A02_F & TC70414 & Cold-regulated protein & 2.28 & $1.95 *$ & $0.75^{*}$ & $0.39 *$ & 0.88 \\
\hline $\mathrm{J} 442$ & TC233441 & E2 Ubiquitin ligase & 2.37 & $1.73^{*}$ & $0.62 *$ & $0.36^{*}$ & 0.85 \\
\hline
\end{tabular}


Table 3 (concluded).

\begin{tabular}{llllrccc}
\hline & TIGR & & Control & Spring & $\begin{array}{l}\text { Winter } \\
\text { induction }\end{array}$ & $\begin{array}{l}\text { Induction } \\
\text { W/S }\end{array}$ & $\begin{array}{l}\text { Expression } \\
\text { W/S }\end{array}$ \\
\hline J342 & TC68241 & Hypothetical protein & 2.35 & $1.66^{*}$ & $0.43^{*}$ & $0.26^{*}$ & 0.61 \\
J626 & TC63138 & Cell wall-associated hydrolase & 3.10 & $1.73^{*}$ & $0.41^{*}$ & $0.24^{*}$ & 0.73 \\
J854 & TC87536 & LEA/RAB-related COR & 7.20 & $12.55^{*}$ & $2.64 *$ & $0.21^{*}$ & $1.51^{*}$ \\
\hline
\end{tabular}

Note: TIGR accessions are the most similar sequence in the TIGR Wheat Gene Index, V6. Control W/S is the relative level of mRNA in control winter wheat plants compared with control spring wheat plants. It is calculated indirectly. Induction of W/S was calculated as the rate of induction or repression in winter wheat divided by the rate of induction or repression in spring wheat. Expression W/S is the relative level of mRNA in winter wheat compared with spring wheat; it was measured directly.

* Statistical significance criteria is $P$-value $\leq 0.05$.

2 cultivars was calculated arithmetically from other hybridization measurements and is included in Tables 3 and 4.

\section{Cluster analysis}

Cluster analysis was used to further characterize differences in gene expression between the freezing-tolerant winter wheat and the less freezing-tolerant spring wheat. Genes with detectable expression for all 3 time points in winter wheat and significant up- or down-regulation for at least 1 time point were used for cluster analysis. Clustering included 215 genes that were characterized in winter wheat and 136 genes that were characterized in spring wheat; the results are available as supplementary data in Figs. S1 and S2, respectively. ${ }^{3}$ To facilitate the detection of differences and similarities of gene expression in the 2 cultivars, the combined data sets for the 2 cultivars, which included 125 common genes, were clustered together. The results are available as supplementary data in Fig. S3. ${ }^{3}$ Genes in the combined data set from winter and spring wheat were grouped into 23 clusters. Those genes whose expression patterns differed in 'Norstar' and 'Glenlea' are readily observed since they did not cluster together in supplementary Fig. S3. ${ }^{3}$ The analysis of coclustering of the 128 genes for which complete data exists for both cultivars revealed that 48 genes show highly similar patterns of expression in the 2 cultivars in that they were grouped into the same cluster. Fifty-three genes showed similar patterns of expression but had some quantitative differences at 1 or more time periods. They were grouped into different clusters that had somewhat similar profiles. More striking differences in patterns of expression were observed for 21 genes that were grouped into distinct clusters with clearly different patterns of expression; these are shown in Fig. 2. The observed qualitative or quantitative changes in expression patterns strongly suggest that important differences exist in cold signaling pathways between cultivars and these genes represent candidates for the elucidation of these pathways. Below is a brief discussion of genes with important differences in expression in the 2 cultivars and their possible role in the cold acclimation process.

\section{Signal transduction and novel genes}

Many genes encoding regulatory type proteins (C176, C288, C338, C652, F29_R, J293, J621, J713, J770, J772, J822, J840, J878, J900, J904, J925, S31_F, S42_F, had altered expressions in cold-treated plants, some of which had significantly different expressions in the 2 cultivars. The majority of these genes had fewer than 2-fold changes in ex- pression, though a few of the genes in this class had high levels of upregulation. The quantitative nature of microarray analysis is well suited to the detection of subtle changes of expression, since such changes are easily overlooked in classical screening methods such as differential screening of cDNA clones, differential display, and northern analysis. In the case of signal transduction components, subtle changes in cellular levels can be significant since the signal is amplified downstream. The level of transcript for J900, which encodes a calcium-binding EF-hand protein, was upregulated 2.9- and 9.0-fold at 36 days of cold acclimation in spring and winter wheat, respectively. Levels of F29_R, which encodes an LRK10-like protein kinase, were induced 3.2-fold in winter wheat at 36 days of cold acclimation and transcript levels for $\mathrm{C} 288$, which encodes a protein kinase, were 2.8fold higher in winter wheat at 6 days of LT treatment. Although a number of other genes in this class, including protein kinases, protein phosphatases, transcription factors, RNA-binding protein, a 14-3-3 homolog, and a Ras-related GTP-binding protein, had altered expression in at least 1 cultivar for at least 1 time point (supplementary Table $S 2^{3}$ ), significant differences were not detected between the 2 cultivars. Regulatory genes with differential expression between the 2 cultivars are high priority candidates for further characterization.

\section{Photosynthesis and carbon fixation}

A large number of genes encoding proteins involved in photosynthesis and carbon fixation had altered expressions in response to cold treatment. A number of these genes were differentially expressed in the winter and spring cultivars. Many of these genes are members of gene families whose members showed similar patterns of expression. There is a tendency for photosynthesis genes to be downregulated by LT, and the most accentuated differences between spring and winter wheat occur after 36 days of growth at LT when photosynthesis-related genes tend to be downregulated in winter wheat relative to spring wheat. Genes, encoding the rubisco small subunit, carbonic anhydrase, and PSI antenna proteins are repressed in winter wheat after 36 days of cold acclimation, whereas they are either induced or expressed at control levels in spring wheat (Table 4 and supplementary Table $\mathrm{S}^{3}$ ). Chlorophyll a/b-binding proteins, in contrast with other genes encoding proteins involved in photosynthesis, were upregulated after 1 and 6 days of cold treatment in both cultivars. They remained significantly upregulated in the spring cultivar at 36 days, whereas in the winter cultivar 
Table 4. Genes with different induction or expression winter and spring wheat at 36 days of cold acclimation. W/S, winter/spring; LT, low temperature.

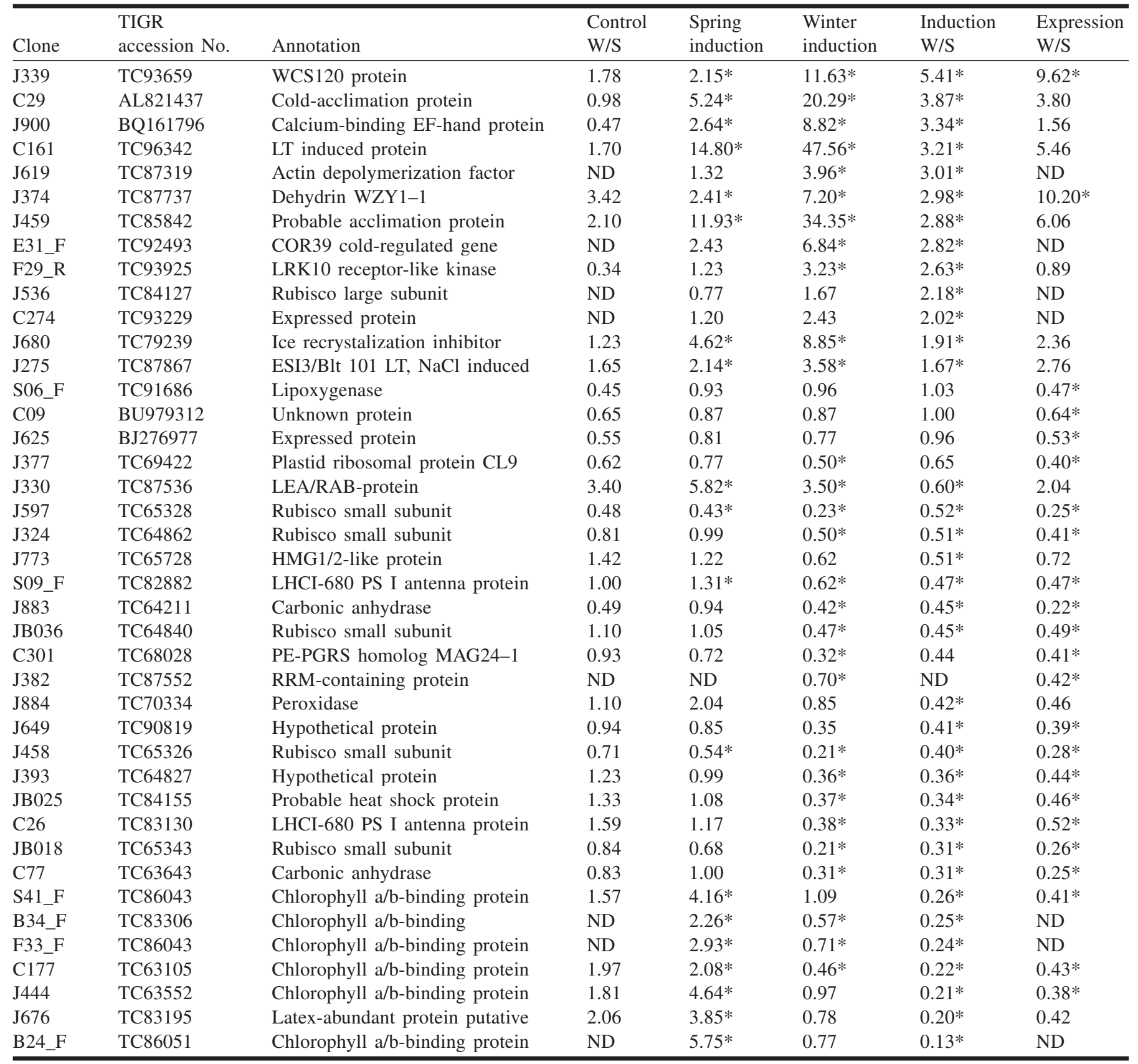

Note: TIGR accessions are the most similar sequence in the TIGR Wheat Gene Index, V6. Control W/S is the relative level of mRNA in control winter wheat plants compared with control spring wheat plants. It is calculated indirectly. Induction W/S was calculated as the rate of induction or repression in winter wheat divided by the rate of induction or repression in spring wheat. Expression W/S is the relative level of mRNA in winter wheat compared with spring wheat; it was measured directly.

* Statistical significance criteria is $P$-value $\leq 0.05$.

these genes returned to control levels after 36 days of cold acclimation.

A shift of warm-grown plants to LT can result in an imbalance between the light energy absorbed through photochemistry and the energy utilized through metabolism (Huner et al. 1998). This imbalance is the result of the lightharvesting and $\mathrm{O}_{2}$ generation reactions that are temperature independent and the kinetics of the carbon fixation pathway that is slowed by LT. The excess level of light excitation can lead to oxidative damage due to a higher level of unutilized electrons. Excess electrons can damage photosystem subunits, particularly the PSII D1 reaction center, leading to an increased production of reactive oxygen species.

Transcripts for light-harvesting complex chlorophyllbinding proteins of the outer antenna of PSII and the inner antenna of PSI have been shown to be regulated by cold treatment in Arabidopsis; however, their patterns of regulation were quite different from those observed in our experi- 
Fig. 2. Selected genes that showed distinct clustering patterns in samples from winter and spring wheat. Columns $1-3$ show the expression ratios for treatment/control of the winter wheat 'Norstar' treated at $4{ }^{\circ} \mathrm{C}$ for 1,6 , and 36 days. Columns $5-7$ show the induction ratio of the spring wheat 'Glenlea' treated at $4{ }^{\circ} \mathrm{C}$ for 1,6 , and 36 days, respectively. Values are based on $\log _{2}$ ratios.

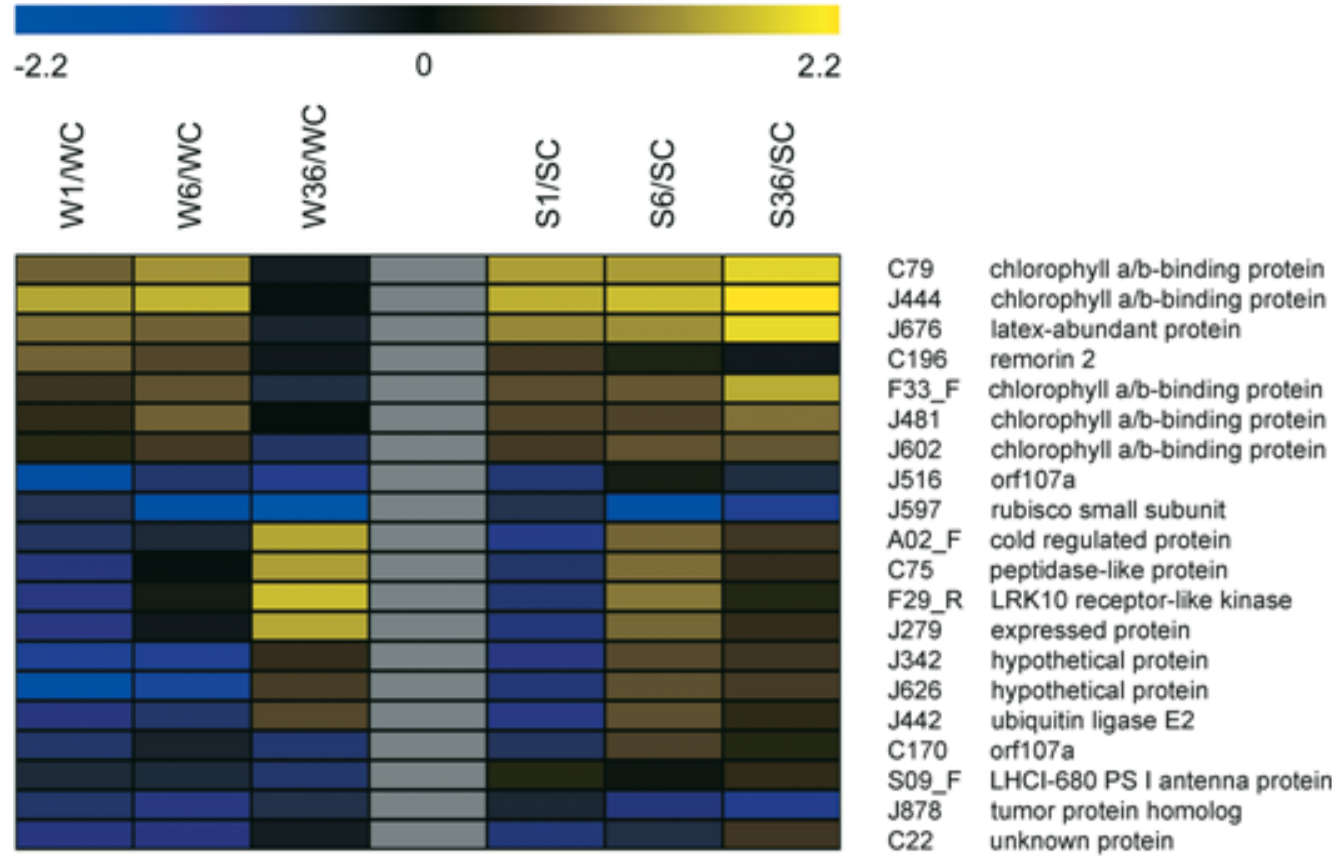

ments (Strand et al. 1997). Though the experimental conditions and the days of sampling in the Arabidopsis work were not identical to the experiments reported here, the comparison of patterns of expression indicates a different response to cold in these 2 species and between the 2 wheat cultivars. In Arabidopsis, these genes show a rapid decline in transcript levels at 1 day of cold treatment and a partial and gradual recovery over 21 days (Strand et al. 1997). In wheat, transcripts show little change after 1 and 6 days of acclimation, but at 36 days the spring wheat shows a small increase in transcript levels, whereas the winter wheat shows a reduction of transcripts for these genes. The biochemical significance of the decreased gene expression for photosynthesis-related genes in winter wheat warrants further investigation. It may reflect a decrease in the light-harvesting apparatus that would reduce the imbalance between lightharvesting and dark reactions; it may also reflect reduced damage and consequently reduced recycling of proteins of the photosynthetic apparatus of winter wheat compared with spring wheat.

\section{Oxidative stress}

In our study, peroxidase (J884) transcript levels are more strongly upregulated in spring wheat than in winter wheat at 1 day and at 36 days (Table 4 and supplementary Table $S 1^{3}$ ). Peroxidase plays a role in detoxification of peroxide, an active oxygen species that is enhanced by cold stress, and changes in peroxidase expression in cold-stressed plants has been previously described in several species (e.g., Anderson et al. 1995). The disruption of photosynthesis by cold increases the reduction state of components of the photosynthetic apparatus that contributes to increased reactive oxygen species. A peroxidase was shown to be transiently induced early in cold treatment and was again upregulated at 7 days of cold
Fig. 3. Gene expression profile for selected genes. Transcript levels of cold-regulated genes C86, a glycine-rich protein; F29, a receptor-like kinase; J822, guanine nucleotide regulatory protein; J882, an inorganic pyrophosphatase; J900, a calcium-binding EFhand protein; J925, a GTP-binding protein measured by RT-PCR. Seedlings of freezing-tolerant winter cultivar 'Clair' were either kept at $22{ }^{\circ} \mathrm{C}(\mathrm{C})$ or grown at $4{ }^{\circ} \mathrm{C}$ for the periods indicated. Their total RNAs were extracted and used for RT-PCR with gene-specific primers as described in Materials and methods.

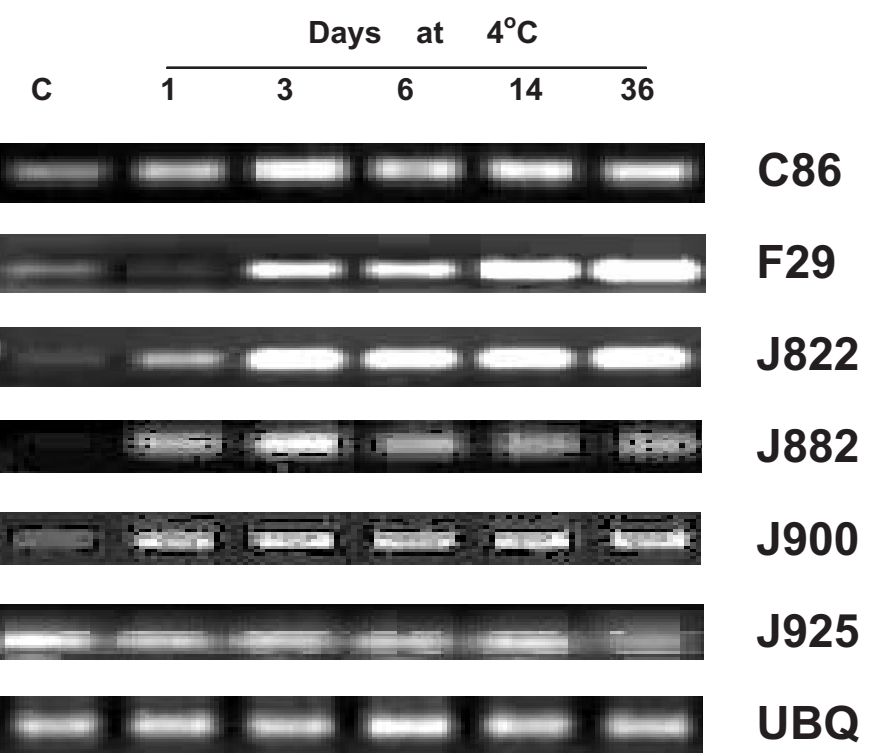

acclimation in Arabidopsis (Fowler et al. 2002). Though longer term treatments were not included in the study, the Arabidopsis pattern is most similar to that observed in spring wheat catalase, which also detoxifies hydrogen perox- 
ide. In winter wheat, the catalase is slightly repressed at 6 days, though it is not statistically different from spring wheat catalase. These patterns show a similarity between spring wheat and Arabidopsis and suggest that winter wheat has evolved additional responses to avoid oxidative stress. The decreased turnover of components of the photosynthetic apparatus may also reflect this adaptation. The data presented here are suggestive since peroxidases are encoded by a gene family of at least 9 members in Arabidopsis (Ostergaard et al. 1998) and the gene expression patterns differ among gene family members (Fowler et al. 2002). Further studies are necessary to fully describe the response of peroxidase genes during cold acclimation in wheat.

\section{Previously known cold-regulated genes}

Microarray analysis identified a large number of genes with relatively strong gene induction during cold acclimation; in some cases genes showed greater than 20-fold induction. Many such genes are seen in clusters 1 to 6 for winter wheat in supplementary Fig. $\mathrm{S}^{3}$ and include a large number of the previously described cold acclimation-induced genes. These include WCS120 (Houde et al. 1992, Saran et al. 1997), actin depolymerizing factor-like (Danyluk et al. 1996), WCOR615, WCOR80, WCOR825 (Danyluk 1997), J330 a cold-responsive late embryogenesis abundant (LEA)/ RAB-related protein (Tsuda et al. 2000), phosphoethanolamine methyltransferase (Frenette Charron et al. 2002), WCOR14a (N'Dong et al. 2002), and WCOR413 (Breton et al. 2003). Expression patterns for these genes are similar to what was previously obtained by northern blot analysis, thus supporting the accuracy of the microarray analysis. Other strongly induced genes in these clusters such as the icerecrystalization inhibitor protein were previously described in carrot (Worrall et al. 1998) and in wheat (Tremblay et al. 2005).

\section{Validation of microarray data for selected cold- regulated transcripts}

Several genes that were observed to have altered transcript levels and differential expression between the 2 cultivars in the microarray analysis were selected for confirmation of transcript changes by RT-PCR. The genes include C86, F29, J822, J900, and J925. Their BLAST-based annotations are glycine rich protein, a receptor-like kinase, guanine nucleotide regulatory protein, calcium-binding EF-hand protein, and Ras-related GTP-binding protein, respectively. All but J822, which was downregulated, were found to be upregulated in the more freezing-tolerant cultivar (Table 1). The majority of the selected clones are from genes that have not been previously characterized as being cold-regulated proteins in wheat and represent genes that showed a range of changes in transcript levels by microarray analysis from less than 2-fold to more than 5-fold. Transcript levels were measured over a time course of cold acclimation of 1,6 , and 36 days in 'Norstar'-derived winter cultivar 'Clair', $\mathrm{LT}_{50}-19{ }^{\circ} \mathrm{C}$.

As can be seen in Fig. 3, the pattern of expression revealed by RT-PCR is in general agreement with that of the microarray. However, in the case of J822, the micorarray data predicted strong increases before day 6 and a weaker increase after, whereas the RT-PCR data showed a reverse trend. In light of the potential regulatory roles of these genes, we are conducting further studies that may clarify this discrepancy.

These results together with those obtained in previous studies with known cold-regulated genes strongly support the reliability of the data obtained by microarray analysis.

\section{Conclusions}

Microarray analysis led to the discovery of 43 novel genes that were differentially regulated between spring and winter cultivars. These genes and their products are good candidates for functional analysis using bioinformatic, biochemical, and genetic approaches. In addition, a large number of novel cold-regulated genes were detected that were not necessarily differentially regulated between the 2 cultivars. The identification of this large number of novel genes using transcription profiling demonstrates that microarray analysis for genotype comparisons is an extremely useful approach to characterizing differences in gene expression associated with superior freezing tolerance.

\section{Acknowledgements}

We thank Irena Al-Khairy, Uppsala, Sweden, Zina Hussein, Wucheng Liu, and Mohammed Ridha for their excellent technical assistance with PCR and bioinformatics. We thank the Centre for Structural and Functional Genomics, Concordia University, for substantial assistance in microarray construction and analysis. This work was supported by grants from the Natural Sciences and Engineering Research Council of Canada to P.J.G. and F.S., and by a Genome Canada, Genome Prairie, and Genome Quebec grant to P.J.G. and F.S.

\section{References}

Anderson, M.D., Prasad, T.K., and Stewart, C.R. 1995. Changes in isozyme profiles of catalase, peroxidase, and glutathione reductase during acclimation to chilling in mesocotyls of maize seedlings. Plant Physiol. 109: 1247-1257.

Benjamini, Y., and Hochberg, Y. 1995. Controlling the false discovery rate: a practical and powerful approach to multiple testing. J. Roy. Stat. Soc. B. 57: 289-300.

Breton, G., Danyluk, J., Frenette Charron, J.B., and Sarhan, F. 2003. Expression profiling and bioinformatic analyses of a novel stress-regulated multispanning transmembrane protein family from cereals and Arabidopsis. Plant Physiol. 132: 64-74.

Casati, P., and Walbot, V. 2003. Gene expression profiling in response to ultraviolet radiation in maize genotypes with varying flavonoid content. Plant Physiol. 132: 1739-1754.

Chauvin, L.P., Houde, M., and Sarhan, F. 1993. A leaf-specific gene stimulated by light during wheat acclimation to low temperature. Plant Mol. Biol. 23: 255-265.

Danyluk, J. 1997. Identification et caractérisation moléculaire de gènes induits au cours de l'acclimatation au froid chez le blé (Triticum aestivum). Thèse de doctorat en biologie moléculaire. Université de Montréal, Montréal, Québec.

Danyluk, J., and Sarhan, F. 1990. Differential mRNA transcription during the induction of freezing tolerance in spring and winter wheat. Plant Cell Physiol. 31: 609-619.

Danyluk, J., Houde, M., Rassart, É., and Sarhan, F. 1994. Differential expression of a gene encoding an acidic dehydrin in chilling 
sensitive and freezing tolerant Gramineae species. FEBS Lett. 344: 20-24.

Danyluk, J., Carpentier, É., and Sarhan, F. 1996. Identification and characterization of a low temperature regulated gene encoding an actin-binding protein from wheat. FEBS Lett. 389: 324-327.

Desikan, R., A-H-Mackerness, S., Hancock, J.T., and Neill, S.J. 2001. Regulation of the Arabidopsis transcriptome by oxidative stress. Plant Physiol. 127: 159-172.

Ewing, B., and Green, P. 1998. Basecalling of automated sequencer traces using pred. II. Error probabilities. Genome Res. 8: $186-194$.

Fowler, S., and Thomashow, M.F. 2002. Arabidopsis transcriptome profiling indicates that multiple regulatory pathways are activated during cold acclimation in addition to the CBF cold response pathway. Plant Cell, 14: 1675-1690.

Frenette Charron, J.B., Breton, G., Danyluk, J., Muzac, I., Ibrahim, R., and Sarhan, F. 2002. Molecular and biochemical characterization of a cold regulated phosphoethanolamine N-methyltransferase from wheat. Plant Physiol. 129: 363-373.

Hegde, P., Qi, R., Abernathy, K., Gay, C., Dharap, S., Gaspard, R., Hughes, J.E., Snesrud, E., Lee, N., and Quackenbush, J. 2000. A concise guide to cDNA microarray analysis. Biotechniques, 29: $548-556$.

Houde, M., Danyluk, J., Laliberté, J.F., Rassart, É., Dhindsa, R.S., and Sarhan, F. 1992. Cloning, characterization and expression of a cDNA encoding a $50 \mathrm{kD}$ protein specifically induced by cold acclimation in wheat. Plant Physiol. 99: 1381-1387.

Huner, N.P.A., Öquist, G., and Sarhan, F. 1998. Energy balance and acclimation to light and cold. Trends Plant Sci. 3: 224-230.

Kawasaki, S., Borchert, C., Deyholos, M., Wang, H., Brazille, S., Kawai, K., Galbraith, D., and Bohnert, H.J. 2001. Gene expression profiles during the initial phase of salt stress in rice. Plant Cell, 13: 889-905.

Kreps, J.A., Wu, Y., Chang, H.S., Zhu, T., Wang, X., and Harper, J.F. 2002. Transcriptome changes for Arabidopsis in response to salt, osmotic, and cold stress. Plant Physiol. 130: 2129-2141.

N'Dong, C., Danyluk, J., Wilson, K.E., Huner, N.P.A., and Sarhan, F. 2002. Cold regulated cereal chloroplast late embryogenesis abundant-like proteins: molecular characterization and functional analyses. Plant Physiol. 129: 1368-1381.

Oono, Y., Seki, M., Nanjo, T., Narusaka, M., Fujita, M., Satoh, R., Satou, M., Sakurai, T., Ishida, J., Akiyama, K., Iida, K.,
Maruyama, K., Satoh, S., Yamaguchi-Shinozaki, K., and Shinozaki, K. 2003. Monitoring expression profiles of Arabidopsis gene expression during rehydration process after dehydration using ca. 7000 full-length cDNA microarray. Plant J. 34: 868-887.

Ostergaard, L., Pedersen, A.G., Jespersen, H.M., Brunak, S., and Welinder, K.G. 1998. Computational analyses and annotations of the Arabidopsis peroxidase gene family. FEBS Lett. 433: 98-102.

Rosen, K.M., and Villa-Komaroff, L. 1990. An alternative method for the visualization of RNA in formaldehyde agarose gels. Focus, 12: 23-24.

Sambrook, J., Fritsch, E.F., and Maniatis, T. 1989. Molecular cloning: a laboratory manual. 2nd ed. Cold Spring Harbor Laboratory Press, Cold Spring Harbor, New York.

Sarhan, F., Ouellet, F., and Vazquez-Tello, A. 1997. The wheat wcs 120 gene family: a useful model to understand the molecular genetics of freezing tolerance in cereals. Physiol. Plant, 101: 439-445.

Strand, A., Hurry, V., Gustafsson, P., and Gardestrom, P. 1997. Development of Arabidopsis thaliana leaves at low temperatures releases the supression of photosynthesis and photosynthetic gene expression despite the accumulation of soluble carbohydrates. Plant J. 12: 605-614.

Sturn, A., Quackenbush, J., and Trajanoski, Z. 2002. Genesis: cluster analysis of microarray data. Bioinformatics, 18(1): 207-208.

Tremblay, K., Ouellette, F., Fournier, J., Danyluk, J., and Sarhan, F. 2005. Molecular characterization and origin of novel bipartite cold-regulated ice recrystalization inhibition proteins from cereals. Plant Cell Physiol. 6: 884-891.

Tsuda, K., Tsvetanov, S., Takumi, S., Mori, N., Atanassov, A., and Nakamura, C. 2000. New members of a cold-responsive group-3 Lea/Rab-related Cor gene family from common wheat (Triticum aestivum L.). Genes Genet. Syst. 75: 179-188.

Worrall, D., Elias, L., Ashford, D., Smallwood, M., Sidebottom, C., Lillford, P., Telford, J., Holt, C., and Bowles, D. 1998. A carrot leucine-rich-repeat protein that inhibits ice recrystallization. Science (Washington, D.C.), 282: 115-117.

Yan, L., Loukoianov, A., Tranquilli, G., Helguera, M., Fahima, T., and Dubcovsky, J. 2003. Positional cloning of the wheat vernalization gene VRN1. Proc. Natl. Acad. Sci. U.S.A. 13(10): 62636268 . 